\title{
In Vitro Antimicrobial Activity of Green Synthesized Silver Nanoparticles Against Selected Gram-negative Foodborne Pathogens
}

\section{OPEN ACCESS}

Edited by:

Rebecca Thombre,

Pune University, India

Reviewed by:

Leda Giannuzzi,

National University of La Plata,

Argentina

M. Oves,

King Abdulaziz University,

Saudi Arabia

*Correspondence:

Yuet Ying Loo

yuetying88@gmail.com

Specialty section: This article was submitted to Antimicrobials, Resistance

and Chemotherapy,

a section of the journal

Frontiers in Microbiology

Received: 28 March 2018

Accepted: 22 June 2018

Published: 16 July 2018

Citation:

Loo YY, Rukayadi Y,

Nor-Khaizura M-A-R, Kuan CH,

Chieng BW, Nishibuchi M and Radu S

(2018) In Vitro Antimicrobial Activity

of Green Synthesized Silver

Nanoparticles Against Selected

Gram-negative Foodborne

Pathogens. Front. Microbiol. 9:1555.

doi: 10.3389/fmicb.2018.01555
Yuet Ying Loo ${ }^{*}$, Yaya Rukayadi', Mahmud-Ab-Rashid Nor-Khaizura1', Chee Hao Kuan², Buong Woei Chieng ${ }^{3,4}$, Mitsuaki Nishibuchi ${ }^{5}$ and Son Radu ${ }^{1,6}$

\begin{abstract}
${ }^{1}$ Department of Food Science, Faculty of Food Science and Technology, Universiti Putra Malaysia, Selangor, Malaysia, ${ }^{2}$ Department of Agricultural and Food Science, Faculty of Science, Universiti Tunku Abdul Rahman, Kampar, Malaysia, ${ }^{3}$ Department of Chemistry, Faculty of Science, Universiti Putra Malaysia, Selangor, Malaysia, ${ }^{4}$ Materials Processing and Technology Laboratory, Institute of Advanced Technology, Universiti Putra Malaysia, Selangor, Malaysia, ${ }^{5}$ Center for Southeast Asian Studies, Kyoto University, Kyoto, Japan, ${ }^{6}$ Laboratory of Food Safety and Food Integrity, Institute of Tropical Agriculture and Food Security (ITAFOS), Universiti Putra Malaysia, Selangor, Malaysia
\end{abstract}

Silver nanoparticles (AgNPs) used in this study were synthesized using pu-erh tea leaves extract with particle size of $4.06 \mathrm{~nm}$. The antibacterial activity of green synthesized AgNPs against a diverse range of Gram-negative foodborne pathogens was determined using disk diffusion method, resazurin microtitre-plate assay (minimum inhibitory concentration, $\mathrm{MIC}$ ), and minimum bactericidal concentration test (MBC). The MIC and MBC of AgNPs against Escherichia coli, Klebsiella pneumoniae, Salmonella Typhimurium, and Salmonella Enteritidis were 7.8, 3.9, 3.9, 3.9 and 7.8, 3.9, 7.8, $3.9 \mu \mathrm{g} / \mathrm{mL}$, respectively. Time-kill curves were used to evaluate the concentration between MIC and bactericidal activity of AgNPs at concentrations ranging from $0 \times \mathrm{MIC}$ to $8 \times \mathrm{MIC}$. The killing activity of AgNPs was fast acting against all the Gram-negative bacteria tested; the reduction in the number of CFU mL ${ }^{-1}$ was $>3 \log _{10}$ units $(99.9 \%)$ in 1-2 $\mathrm{h}$. This study indicates that AgNPs exhibit a strong antimicrobial activity and thus might be developed as a new type of antimicrobial agents for the treatment of bacterial infection including multidrug resistant bacterial infection.

Keywords: silver nanoparticles, tea leave extracts, antimicrobial activity, foodborne pathogens, Gram-negative, time-kill curves

\section{INTRODUCTION}

Recently, nanotechnology has emerged as a dynamically developing area of scientific interest in the world. Nanoparticles are defined as a nanoscale particle of size ranging from 1 to $100 \mathrm{~nm}$. Among the metallic nanoparticles, silver nanoparticles (AgNPs) have gained increasingly attention due to its unique physical, biological and chemical properties. AgNPs are well-known to exhibit a strong antimicrobial activity against various microorganisms such as bacteria, viruses, and fungi due to its smaller in size and large surface area (Franci et al., 2015). AgNPs are also widely used as anti-fungal (Medda et al., 2015), anti-inflammatory (Hebeish et al., 2014), and anti-viral properties (Bekele et al., 2016). 
Green synthesis of AgNPs employing either biological microorganisms or plant extracts has emerged as a simple and alternative to chemical synthesis. Green synthesis method provides advancements over chemical methods as it is environmental friendly and cost effective. Plant extractsmediated synthesis of AgNPs can be advantageous compared with other biological processes as it does not require the process of maintaining the cell cultures and aseptic environments (Loo et al., 2012). Several studies on the green synthesis of AgNPs using plant extracts have been reported (Medda et al., 2015; Ahmed et al., 2016; Dhand et al., 2016; Selvam et al., 2017).

Foodborne illnesses have emerged as a major public health concern around the world. WHO (2014) reported that there is about $30 \%$ of the population in industrialized countries affected by foodborne diseases every year. The consumption of foods contaminated with foodborne pathogens such as bacteria, fungi, viruses, and toxins are often recognized as the main source of foodborne illness in humans. Food especially minimalprocessed food can be contaminated during pre-harvesting, post-harvesting, processing, transport, handling, or preparation. The most common foodborne pathogens found in food are Salmonella spp. (Lee et al., 2015; D’Ostuni et al., 2016), Listeria spp. (Ferreira et al., 2014; Välimaa et al., 2015), Escherichia coli O157 (Heiman et al., 2015), Campylobacter spp. (Kaakoush et al., 2015), and Clostridia spp. (Chukwu et al., 2016).

The presence of multidrug resistance pathogens have increased the number of infectious disease and became the main cause of death in the world (WHO, 2000; Tanwar et al., 2014). Widely misuse and abuse of antibiotics are the leading cause of antibiotic resistance in the bacteria (O'Bryan et al., 2018). Multidrug resistant bacteria infection may lead to several impacts including increase of mortality and morbidity rates, prolong of hospitalization period, and economic loss (Patel et al., 2008). Woh et al. (2017) detected multi-drug resistant non-typhoidal Salmonella among migrant food handlers, which may cause cross-contamination to the food products. Thus, the development of a new and natural antimicrobial agent is needed as there is a growing concern in multidrug resistant foodborne pathogens.

The aim of this study is to determine the antibacterial activity of green synthesized AgNPs against a diverse range of Gram-negative foodborne pathogens by using disk diffusion method, resazurin microtitre-plate assay minimum inhibitory concentration (MIC), minimum bactericidal concentration test $(\mathrm{MBC})$, and time-kill curve assay.

\section{MATERIALS AND METHODS}

\section{Preparation of Silver Nanoparticles}

The synthesis of AgNPs using pu-erh tea leaves extracts was done using the method as described previously (Loo et al., 2012). Ten gram of tea leaves was weighed in a beaker. The tea leaves was added with $100 \mathrm{~mL}$ of distilled water and maintained at $60^{\circ} \mathrm{C}$ for $10 \mathrm{~min}$. After $10 \mathrm{~min}$, the tea extract was filtered using $0.45 \mu \mathrm{m}$ Millipore membrane filter and followed by $0.2 \mu \mathrm{m}$ Millipore membrane filter. For synthesis of AgNPs, $12 \mathrm{~mL}$ of tea extracts was added into $100 \mathrm{~mL}$ of $\mathrm{AgNO}_{3}(1 \mathrm{mM})$ in Erlenmeyer flask at room temperature. Color changes of the solution were observed. The synthesized AgNPs were characterized by UV-vis spectroscopy, X-ray diffraction (XRD), Fourier transform infrared (FTIR) spectroscopy, and transmission electron microscopy (TEM).

\section{Bacteria Strains Preparation}

Escherichia coli ATCC 25922 (E. coli), Klebsiella pneumoniae ATCC 13773 (K. pneumoniae), Salmonella Typhimurium ATCC 14028 (S. Typhimurium), and Salmonella Enteritidis ATCC 13076 (S. Enteritidis) were obtained from the American Type Culture Collection (Rockville, MD, United States). All the bacteria strains were cultured in Mueller Hinton broth (MHB) (Merck, Germany) at $37^{\circ} \mathrm{C}$ for $24 \mathrm{~h}$ with $200 \mathrm{rpm}$ agitation.

\section{Preparation of Resazurin Solution}

The resazurin solution was prepared at $0.02 \%$ (wt/vol) according to Khalifa et al. (2013). A $0.002 \mathrm{~g}$ of resazurin salt powder was dissolved in $10 \mathrm{~mL}$ of distilled water and vortexed. The mixture was filtered by Millipore membrane filter $(0.2 \mu \mathrm{m})$. The resazurin solution can be kept at $4^{\circ} \mathrm{C}$ for 2 weeks.

\section{In Vitro Susceptibility Test Disk Diffusion Method}

The antibacterial activity of AgNPs against the selected Gramnegative foodborne pathogens was carried out using Kirby-Bauer Disk Diffusion Susceptibility Test method (Bauer et al., 1966). The bacteria strains were spread on the Mueller-Hinton agar (MHA) (Merck, Germany) using sterile cotton swab. Sterile blank antimicrobial susceptibility disk was used in the test. The disks were loaded with $10 \mu \mathrm{L}$ of tea leaves extracts, silver nitrate solution $(1 \mathrm{mM})$, and solution containing tea leaves mediated synthesized AgNPs separately. The disks were then placed on the agar plate and incubated at $37^{\circ} \mathrm{C}$ for $24 \mathrm{~h}$. The zone of inhibition was observed after $24 \mathrm{~h}$ of incubation.

\section{Minimum Inhibitory Concentration (MIC) and Minimum Bactericidal Concentration (MBC) Evaluation}

The MIC and MBC of green synthesized AgNPs were done using the method described in the guideline of CLSI (2012). The MIC test was performed in 96-well round bottom microtiter plate using standard broth microdilution methods while the MBC test was performed on the MHA plates. The bacterial inoculums were adjusted to the concentration of $10^{6} \mathrm{CFU} / \mathrm{mL}$. For the MIC test, $100 \mu \mathrm{L}$ of the synthesized AgNPs stock solution $(500 \mu \mathrm{g} / \mathrm{mL})$ was added and diluted twofold with the bacterial inoculums in $100 \mu \mathrm{L}$ of MHB started from column 12 to column 3. Column 12 of the microtiter plate contained the highest concentration of AgNPs, while column 3 contained the lowest concentration. Column 1 served as negative control (only medium) and the column 2 served as positive control (medium and bacterial inoculums). Each well of the microtiter plate was added with $30 \mu \mathrm{L}$ of the resazurin solution and incubated at $37^{\circ} \mathrm{C}$ for $24 \mathrm{~h}$. Any color changes were observed. Blue/purple color indicated no bacterial growth while pink/colorless indicated bacterial growth. 
The MIC value was taken at the lowest concentration of antibacterial agents that inhibits the growth of bacteria (color remained in blue).

The MBC was defined as the lowest concentration of the antibacterial agents that completely kill the bacteria. MBC test was performed by plating the suspension from each well of microtiter plates into MHA plate. The plates were incubated at $37^{\circ} \mathrm{C}$ for $24 \mathrm{~h}$. The lowest concentration with no visible growths on the MHA plate was taken as MBC value.

\section{Time-Kill Curve}

Time-kill assay was done in MHB medium as described by Zainin et al. (2013) and Lau et al. (2014). The bacterial inoculums were adjusted to $10^{6} \mathrm{CFU} / \mathrm{mL}$. The AgNPs solution was diluted with MHB media containing bacterial inoculums to obtain the final concentration of $0 \times$ MIC, $0.5 \times$ MIC, $1 \times$ MIC, $2 \times$ MIC, $4 \times$ MIC, and $8 \times$ MIC for each type of bacteria in the total final volume of $1 \mathrm{~mL}$. The cultures were then incubated at $37^{\circ} \mathrm{C}$ with $150 \mathrm{rpm}$ agitation. The cultures $(100 \mu \mathrm{L})$ were spread on MHA plates at time $0,0.25,0.5,1,2$, and $4 \mathrm{~h}$. The experiment was carried out in triplicate. The number of colonies on the MHA plates was quantified in $\mathrm{CFU} / \mathrm{mL}$ after incubation at $37^{\circ} \mathrm{C}$ for 24 h. For statistical analysis, SPSS (v.19) statistical package was used to determine the significant $(P<0.05)$ difference among the tested foodborne pathogens.

\section{RESULTS AND DISCUSSION}

This study was aimed to determine the antibacterial effect of green synthesized AgNPs. The green synthesized AgNPs used in this study were characterized by UV-vis spectroscopy, XRD, FTIR spectroscopy, and TEM. The XRD patterns for synthesized AgNPs showed that five main characteristic diffraction peaks for $\mathrm{Ag}$ were observed at $2 \theta=38.4,44.5,64.8,77.7$, and 81.7, which correspond to the (111), (200), (220), (311), and (222) crystallographic planes of face-centered cubic (fcc) Ag crystals. The UV-vis absorption spectrum of the synthesized AgNPs showed a broad peak at $436 \mathrm{~nm}$ which is a characteristic band for Ag. Three infrared bands were observed at 3,271, 1,637, and $386 \mathrm{~cm}^{-1}$ in FTIR measurement. The band at 3,271 and $1,637 \mathrm{~cm}^{-1}$ indicated that the presence of protein as capping agent for AgNPs which increases the stability of the nanoparticles, while the broad peak at $386 \mathrm{~cm}^{-1}$ corresponded to the Ag metal. TEM image revealed that the AgNPs is spherical with the particle size of $4.06 \mathrm{~nm}$ (Loo et al., 2012).

The antibacterial activity of AgNPs was determined against four species of Gram-negative foodborne pathogens: E. coli ATCC 25922, K. pneumoniae ATCC 13773, S. Typhimurium ATCC 14028, and S. Enteritidis ATCC 13076. The results for disk diffusion test, MIC and MBC of the AgNPs are summarized in Table 1. For the disk diffusion test, the presence of clear zone around the AgNPs disk suggesting that the AgNPs possessed antibacterial activity which is able to inhibit the growth of the Gram-negative foodborne pathogens. As previous study by Guzman et al. (2012), reported that AgNPs employed antibacterial activity on Gram-negative bacteria. The visible clear zone produced by AgNPs against four different species of Gramnegative bacteria is showed in Figure 1.

Disk diffusion test was described as the preliminary study in screening the antibacterial activity of an antimicrobial agent; therefore, a further evaluation in determining the antibacterial activity of AgNPs using MIC value was needed (Burt, 2004). MIC was defined as the lowest concentration of the antibacterial agent to inhibit the growth of bacteria by serial dilution. As showed in Table 1, the MIC values of AgNPs against the foodborne pathogens were ranged from 3.9 to $7.8 \mu \mathrm{g} / \mathrm{mL}$. K. pneumonia, $S$. Typhimurium and $S$. Enteritidis showed the MIC value of $3.9 \mu \mathrm{g} / \mathrm{mL}$ while $E$. coli showed the MIC value of $7.8 \mu \mathrm{g} / \mathrm{mL}$. $\mathrm{MBC}$ is the lowest concentration of antibacterial agent to kill the bacteria (showed no growth on the agar plate). In the study, MBC for K. pneumoniae and S. Enteritidis were $3.9 \mu \mathrm{g} / \mathrm{mL}$ while $S$. Typhimurium and E. coli showed the MBC value of $7.8 \mu \mathrm{g} / \mathrm{mL}$. The MIC and MBC value of E. coli showed that E. coli was less susceptible to AgNPs. This may due to the positive charges of AgNPs trapped and blocked by lipopolysaccharide, thus make E. coli less susceptible to AgNPs (Lara et al., 2010b).

Resazurin dye was used in the study as an indicator in the determination of cell growth, especially in cytotoxicity assays (McNicholl et al., 2007). Oxidoreductases within viable cells reduced the resazurin salt to resorufin and changed the color from blue non-fluorescent to pink and fluorescent. According to McNicholl et al. (2007), resazurin dye has been applied for decades to check for the bacterial and yeast contamination in milk.

The time kill activity of four foodborne pathogens is shown in Figure 2. The bactericidal activity of AgNPs is effective against the selected Gram-negative pathogens; the reduction in the number of $\mathrm{CFU} / \mathrm{mL}$ was $\geq 3 \mathrm{Log}$ units (99\%). The bactericidal endpoint of AgNPs for E. coli was reached after $2 \mathrm{~h}$ of incubation at $4 \times \operatorname{MIC}(31.2 \mu \mathrm{g} / \mathrm{mL})$ and $8 \times \operatorname{MIC}(62.4 \mu \mathrm{g} / \mathrm{mL})$; while for $K$. pneumoniae, the bacteria was killed after $2 \mathrm{~h}$ of incubation at $2 \times \operatorname{MIC}(7.8 \mu \mathrm{g} / \mathrm{mL}), 4 \times \operatorname{MIC}(15.6 \mu \mathrm{g} / \mathrm{mL})$, and $8 \times \mathrm{MIC}$ $(31.2 \mu \mathrm{g} / \mathrm{mL}) . S$. Typhimurium was killed after $1 \mathrm{~h}$ of incubation at $4 \times \operatorname{MIC}(15.6 \mu \mathrm{g} / \mathrm{mL})$ and $8 \times \operatorname{MIC}(31.2 \mu \mathrm{g} / \mathrm{mL})$. The bactericidal endpoint of AgNP for $S$. Enteritidis was reached after $2 \mathrm{~h}$ of incubation at $2 \times \mathrm{MIC}(7.8 \mu \mathrm{g} / \mathrm{mL})$ and $4 \times$ MIC $(15.6 \mu \mathrm{g} / \mathrm{mL})$; however, the end point reached faster after $1 \mathrm{~h}$ of incubation at $8 \times \operatorname{MIC}(31.2 \mu \mathrm{g} / \mathrm{mL})$. No significant differences $(P>0.05)$ were found among the tested Gramnegative foodborne pathogens. This indicates that AgNPs are

TABLE 1 | The diameter of zone inhibition $(\mathrm{mm})$, MIC value $(\mu \mathrm{g} / \mathrm{mL})$, and MBC value $(\mu \mathrm{g} / \mathrm{mL})$.

\begin{tabular}{lccc}
\hline Bacteria & $\begin{array}{c}\text { Diameter of } \\
\text { inhibition } \\
\text { zone }(\mathbf{m m})\end{array}$ & MIC $(\boldsymbol{\mu g} / \mathbf{m L})$ & MBC $(\boldsymbol{\mu g} / \mathbf{m L})$ \\
\hline Escherichia coli & 15 & 7.8 & 7.8 \\
Klebsiella pneumoniae & 10 & 3.9 & 3.9 \\
Salmonella Typhimurium & 20 & 3.9 & 7.8 \\
Salmonella Enteritidis & 20 & 3.9 & 3.9
\end{tabular}



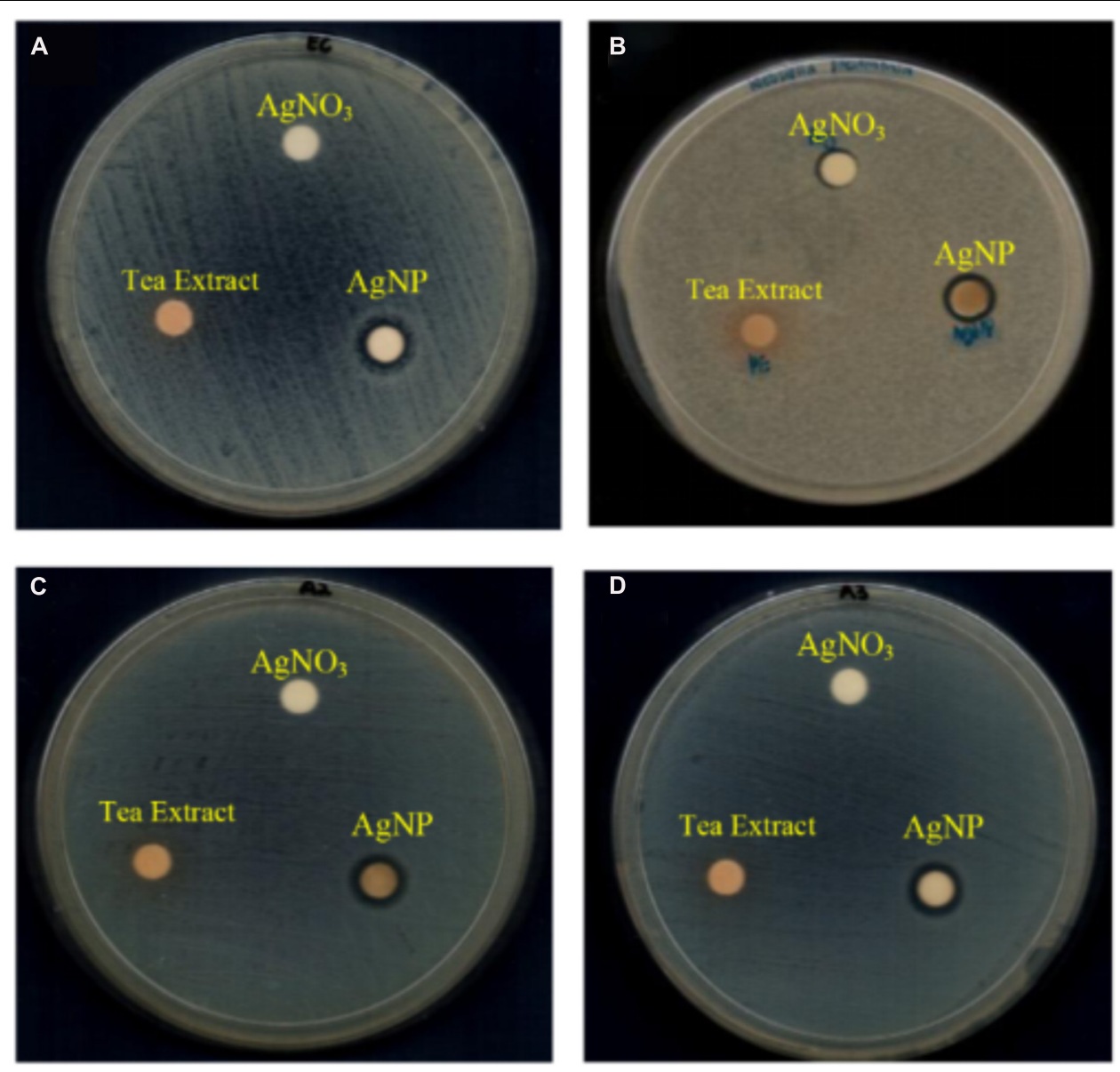

FIGURE 1 | Visible clear zone produced by tea leaves extract mediated AgNP against four species of foodborne pathogens: (A) E. coli ATCC 25922, (B) K. pneumoniae ATCC 13773, (C) S. Typhimurium ATCC 14028, and (D) S. Enteritidis ATCC 13076.

broad spectrum antimicrobial agents which exert the same effect to all Gram-negative bacteria strains.

Silver nanoparticles are well-known as the most universal antimicrobial substances due to their strong biocidal effect against microorganisms, which has been used for over the past decades to prevent and treat various diseases (Oei et al., 2012). AgNPs are also widely used as anti-fungal (Kim et al., 2009), antiinflammatory (Nadworny et al., 2010), and anti-viral properties (Lara et al., 2010a). Recently, non-hazardous AgNPs can easily be synthesized using a cost-effective method and tested as a new type of antimicrobial agents.

In this study, the application of AgNPs as an antimicrobial agent was tested against selected Gram-negative bacteria on agar plate and liquid medium. The results showed that the tested bacteria could completely inhibit by AgNPs. The inhibition of bacteria growth was reported affected by the concentration of AgNPs and bacteria used in the experiments (Sondi and SalopekSondi, 2004). The green synthesized AgNPs in this study are able to inhibit the high concentration of bacteria (approximately $10^{6} \mathrm{CFU} / \mathrm{mL}$ ). This indicated that AgNPs showed an excellent antimicrobial effect as the high CFU concentration of bacteria used in this study are rarely appeared in real-life systems.
The antibacterial activity of AgNPs has been reported by many researchers. However, the MIC values from the previous studies showed the range through a large extent of variation. Therefore, the comparison of the results is difficult as there is no standard method for determination of antibacterial activity of AgNPs and different methods have been applied by the researchers (Zarei et al., 2014). In this study, AgNPs exhibit a good antibacterial activity against the tested foodborne pathogens. Based on the results, the tested bacteria were able to kill in a shorter time at low concentration of AgNPs. This may due to the cell wall structure of Gram-negative bacteria. The characteristic cell wall structure of Gram-negative bacteria is different from Gram-positive bacteria. Gram-negative bacteria have a cytoplasmic membrane, a thin peptidoglycan layer, and an outer membrane containing lipopolysaccharide. There is a space between the cytoplasmic membrane and the outer membrane called the periplasmic space or periplasm. The periplasmic space contains the loose network of peptidoglycan chains known as the peptidoglycan layer.

The rapid reproduction time of bacteria is one of the main causes of bacteria's infectivity (Lara et al., 2010b). However, the reproduction time of the bacteria could be an ideal way to prevent the viable infection as AgNPs were effective in inhibiting 


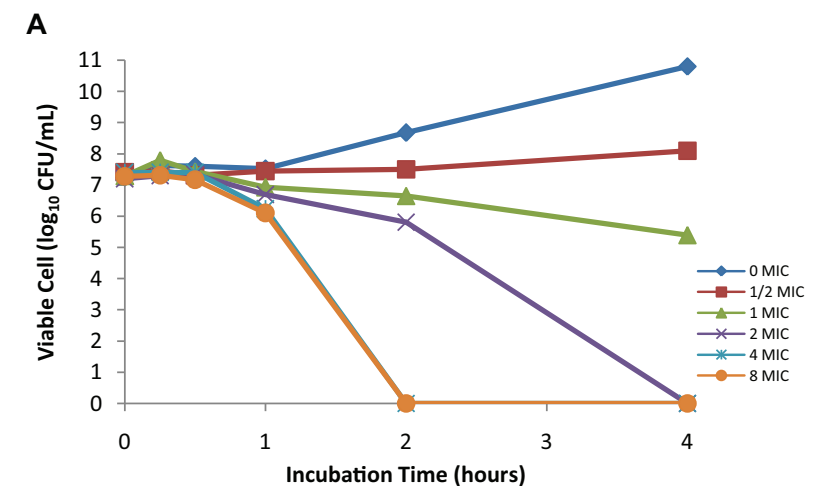

B

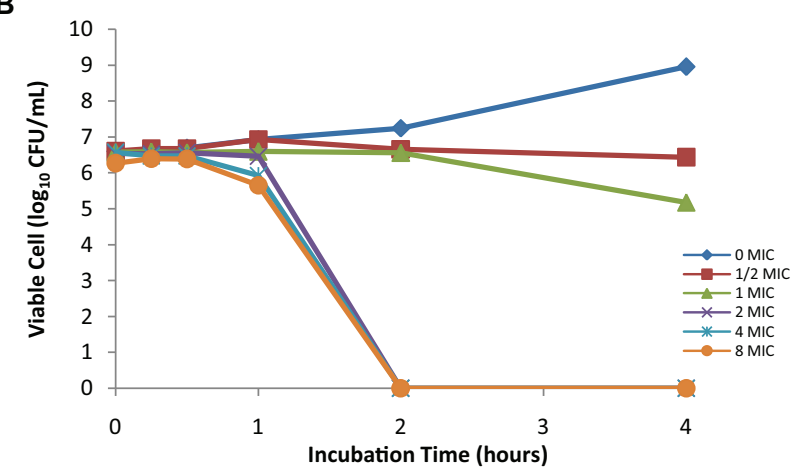

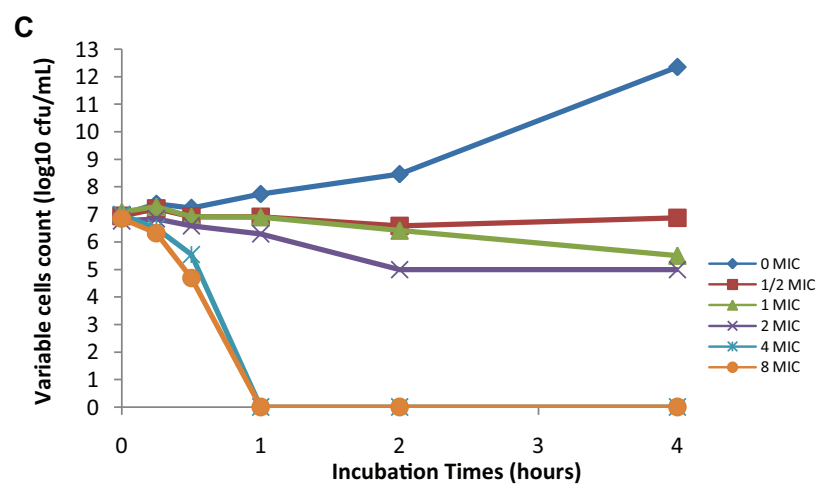

D

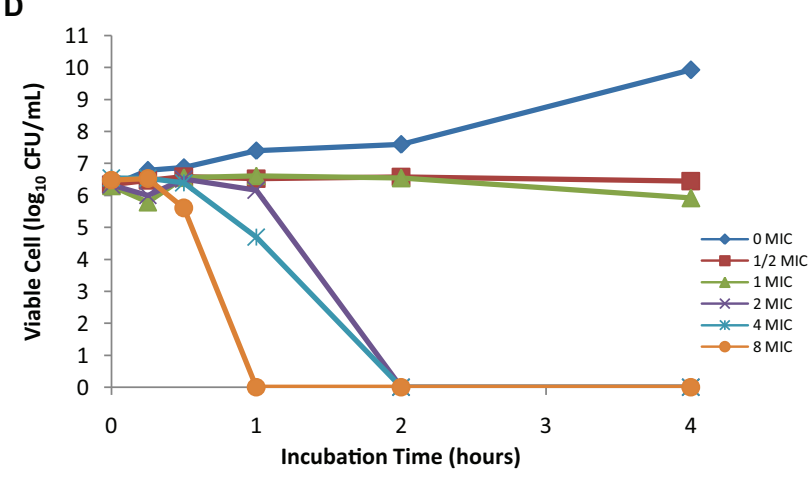

FIGURE 2 | Time-kill plots of AgNPs against (A) E. coli ATCC 25922, (B) K. pneumoniae ATCC 13773, (C) S. Typhimurium ATCC 14028, and (D) S. Enteritidis ATCC 13076 at different concentration and time-length.

and killing the bacteria in a dose and time dependent manner as shown in the time-kill assays. Zhang et al. (2016) reported that the smaller size of AgNPs could cause more toxicity to the bacteria and show better bactericidal effect compared to the larger particles as they have larger surface area. Previous study by Agnihotri et al. (2014) found that the antibacterial efficacy was increased for the AgNPs with less than $10 \mathrm{~nm}$ size. They also concluded that AgNPs with the size of $5 \mathrm{~nm}$ have the fastest antibacterial activity compared to others size of AgNPs.

Silver nanoparticles have emerged as antimicrobial agents against multidrug resistant bacteria due to their high surfacearea-to-volume ration and unique chemical and physical properties. AgNPs have particle size ranging from 1 to $100 \mathrm{~nm}$. The surface area-to-volume ratio of AgNPs increases as the particles size decreases. Morones et al. (2005) reported that AgNPs with the size of 10-100 nm showed strong antimicrobial effect against both Gram-positive and negative bacteria. The small particle size enables AgNPs to adhere to the cell wall and penetrate into the bacteria cell easily, which in turn improves their antimicrobial activity against bacteria. The antimicrobial effects of AgNPs against multidrug resistant bacteria have been studied by many researchers and it was proved that AgNPs are effective against multidrug resistant bacteria such as multidrug resistant E. coli (Paredes et al., 2014; Kar et al., 2016), multidrug resistant strain of Pseudomonas aeruginosa (Durairaj et al., 2012), methicillin-resistant Staphylococcus aureus (MRSA) (Paredes et al., 2014; Yuan et al., 2017), and extended-spectrum $\beta$-lactam
(ESBL) producing bacteria (Doudi et al., 2013; Subashini et al., 2014).

On the other hands, AgNPs are advantageous compared to conventional chemical antimicrobial agents as the major problem caused by the conventional chemical antimicrobial agents is multidrug resistance. The effectiveness of the chemical antimicrobial agents depends on the specific binding of the microorganisms with the surface and metabolites of the antimicrobial agents. However, the chemical antimicrobial agents are limited to use especially in medical field as various microorganisms have developed multiple resistance traits over a period of generations. Thus, the development of AgNPs could be an alternative way to overcome the multidrug resistance microorganisms as bacteria are less likely to develop resistance to metal nanoparticles compared to the conventional antibiotics.

The exact mechanisms of AgNPs against bacteria still remain unknown. However, there are some researchers proposed that the action of AgNPs on bacteria may due to its ability to penetrate into the cell (Sondi and Salopek-Sondi, 2004), the formation of free radicals (Danilczuk et al., 2006; Kim et al., 2007), the inactivation of proteins in the cell by silver ions (Rai et al., 2012) and the production of reactive oxygen species (ROS) (Dakal et al., 2016). Besides that, there are also some factors in affecting the bactericidal mechanisms of AgNPs such as the concentration of AgNPs and bacteria class (Kim et al., 2007; Zhang et al., 2014), shape (Pal et al., 2007; Meire et al., 2012), size 
(Martinez-Castanon et al., 2008), and the combination of various antibiotics (Fayaz et al., 2010; Singh et al., 2013).

\section{CONCLUSION}

Silver nanoparticles showed significant antibacterial activity against the selected Gram-negative foodborne pathogens. Thus, AgNPs might be a good alternative to develop as antibacterial agent against the multidrug-resistant strains of bacteria. The applications of AgNPs may lead to valuable findings in various fields such as medical devices and antimicrobial systems.

\section{AUTHOR CONTRIBUTIONS}

YL, BC, YR, and RS developed the study design. YL and CK carried out the confirmation for the selected foodborne

\section{REFERENCES}

Agnihotri, S., Mukherji, S., and Mukherji, S. (2014). Size-controlled silver nanoparticles synthesized over the range 5-100 nm using the same protocol and their antibacterial efficacy. RSC Adv. 4, 3974-3983. doi: 10.1039/C3RA44507K

Ahmed, S., Ahmad, M., Swami, B. L., and Ikram, S. (2016). A review on plants extract mediated synthesis of silver nanoparticles for antimicrobial applications: a green expertise. J. Adv. Res. 7, 17-28. doi: 10.1016/j.jare.2015.02.007

Bauer, A. W., Kirby, W. M., Sherris, J. C., and Turck, M. (1966). Antibiotic susceptibility testing by a standardized single disk method. Am. J. Clin. Pathol. 45, 493-496. doi: 10.1093/ajcp/45.4_ts.493

Bekele, A. Z., Gokulan, K., Williams, K. M., and Khare, S. (2016). Dose and sizedependent antiviral effects of silver nanoparticles on feline calicivirus, a human norovirus surrogate. Foodborne Pathog. Dis. 13, 239-244. doi: 10.1089/fpd.2015. 2054

Burt, S. (2004). Essential oils: their antibacterial properties and potential applications in foods-a review. Int. J. Food Microbiol. 94, 223-253. doi: 10.1016/j.ijfoodmicro.2004.03.022

Chukwu, E. E., Nwaokorie, F. O., Coker, A. O., Avila-Campos, M. J., Solis, R. L., Llanco, L. A., et al. (2016). Detection of toxigenic Clostridium perfringens and Clostridium botulinum from food sold in Lagos, Nigeria. Anaerobe 42, 176-181. doi: 10.1016/j.anaerobe.2016.10.009

CLSI (2012). Performance Standards for Antimicrobial Susceptibility Testing; Twenty-Second Informational Supplement. Wayne, PA: The Clinical and Laboratory Standards Institute.

Dakal, T. C., Kumar, A., Majumdar, R. S., and Yadav, V. (2016). Mechanistic basis of antimicrobial actions of silver nanoparticles. Front. Microbiol. 7:1831. doi: 10.3389/fmicb.2016.01831

Danilczuk, M., Lund, A., Sadlo, J., Yamada, H., and Michalik, J. (2006). Conduction electron spin resonance of small silver particles. Spectrochim. Acta A Mol. Biomol. Spectrosc. 63, 189-191. doi: 10.1016/j.saa.2005.05.002

Dhand, V., Soumya, L., Bharadwaj, S., Chakra, S., Bhatt, D., and Sreedhar, B. (2016). Green synthesis of silver nanoparticles using Coffea arabica seed extract and its antibacterial activity. Mater. Sci. Eng. C 58, 36-43. doi: 10.1016/j.msec.2015. 08.018

D’Ostuni, V., Tristezza, M., De Giorgi, M. G., Rampino, P., Grieco, F., and Perrotta, C. (2016). Occurrence of Listeria monocytogenes and Salmonella spp. in meat processed products from industrial plants in Southern Italy. Food Control 62, 104-109.

Doudi, M., Naghsh, N., and Setorki, M. (2013). Comparison of the effects of silver nanoparticles on pathogenic bacteria resistant to beta-lactam antibiotics (ESBLs) as a prokaryote model and Wistar rats as a eukaryote model. Med. Sci. Monit. Basic Res. 19, 103-110. doi: 10.12659/MSMBR.883835

Durairaj, R., Amirulhusni, A. N., Palanisamy, N. K., Mohd-Zain, Z., and Ping, L. J. (2012). Antibacterial effect of silver nanoparticles on multi drug pathogens. MN provided culture media and technical advice in the study. YL interpreted the data, drafted the manuscript, and revised the manuscript. YR, M-A-RN-K, CK, BC, and RS checked on the manuscript. All authors read and approved the final version of the manuscript.

\section{FUNDING}

This research was funded by a Research University Grant Scheme Initiative Six (RUGS 6) of Universiti Putra Malaysia (GP-IPS 9438703) and Fundamental Research Grant Scheme (FRGS) of Ministry of Higher Education (MOHE), Malaysia (02-01-141475FR) and, in part, by the Kakenhi Grant-in-Aid for Scientific Research (KAKENHI 24249038), Japan Society for the Promotion of Sciences and grant-in-aid of Ministry of Health, Labor and Welfare, Japan.

resistant Pseudomonas aeruginosa. World Acad. Sci. Eng. Technol. 6, 210-213. doi: 10.12659/MSMBR.883835

Fayaz, A. M., Balaji, K., Girilal, M., Yadav, R., Kalaichelvan, P. T., and Venketesan, R. (2010). Biogenic synthesis of silver nanoparticles and their synergistic effect with antibiotics: a study against Gram-positive and Gram-negative bacteria. Nanomedicine 6, 103-109. doi: 10.1016/j.nano.2009. 04.006

Ferreira, V., Wiedmann, M., Teixeira, P., and Stasiewicz, M. (2014). Listeria monocytogenes persistence in food-associated environments: epidemiology, strain characteristics, and implications for public health. J. Food Prot. 77, 150-170. doi: 10.4315/0362-028X.JFP-13-150

Franci, G., Falanga, A., Galdiero, S., Palomba, L., Rai, M., Morelli, G., et al. (2015). Silver nanoparticles as potential antibacterial agents. Molecules 20, 8856-8874. doi: 10.3390/molecules20058856

Guzman, M., Dille, J., and Godet, S. (2012). Synthesis and antibacterial activity of silver nanoparticles against gram-positive and gram-negative bacteria. Nanomedicine 8, 37-45. doi: 10.1016/j.nano.2011.05.007

Hebeish, A., El-Rafie, M., El-Sheikh, M., Seleem, A. A., and El-Naggar, M. E. (2014). Antimicrobial wound dressing and anti-inflammatory efficacy of silver nanoparticles. Int. J. Biol. Macromol. 65, 509-515. doi: 10.1016/j.ijbiomac.2014. 01.071

Heiman, K. E., Mody, R. K., Johnson, S. D., Griffin, P. M., and Gould, L. H. (2015). Escherichia coli $\mathrm{O} 157$ outbreaks in the United States, 2003-2012. Emerg. Infect. Dis. 21, 1293-1301. doi: 10.3201/eid2108.141364

Kaakoush, N. O., Castaño-Rodríguez, N., Mitchell, H. M., and Man, S. M. (2015). Global epidemiology of Campylobacter infection. Clin. Microbiol. Rev. 28, 687-720. doi: 10.1128/CMR.00006-15

Kar, D., Bandyopadhyay, S., Dimri, U., Mondal, D. B., Nanda, P. K., Das, A. K., et al. (2016). Antibacterial effect of silver nanoparticles and capsaicin against MDRESBL producing Escherichia coli: an in vitro study. Asian Pac. J. Trop. Dis. 6, 807-810. doi: 10.1016/S2222-1808(16)61135-0

Khalifa, R. A., Nasser, M. S., Gomaa, A. A., Osman, N. M., and Salem, H. M. (2013). Resazurin Microtiter Assay Plate method for detection of susceptibility of

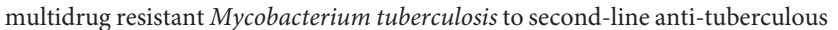
drugs. Egypt. J. Chest Dis. Tuberc. 62, 241-247. doi: 10.1016/j.ejcdt.2013. 05.008

Kim, J. S., Kuk, E., Yu, K. N., Kim, J.-H., Park, S. J., Lee, H. J., et al. (2007). Antimicrobial effects of silver nanoparticles. Nanomedicine 3, 95-101. doi: 10.1016/j.nano.2006.12.001

Kim, K.-J., Sung, W. S., Suh, B. K., Moon, S.-K., Choi, J.-S., Kim, J. G., et al. (2009). Antifungal activity and mode of action of silver nano-particles on Candida albicans. Biometals 22, 235-242. doi: 10.1007/s10534-008-9159-2

Lara, H. H., Ayala-Nuñez, N. V., Ixtepan-Turrent, L., and Rodriguez-Padilla, C. (2010a). Mode of antiviral action of silver nanoparticles against HIV-1. J. Nanobiotechnol. 8:1. doi: 10.1186/1477-3155-8-1 
Lara, H. H., Ayala-Núnez, N. V., Turrent, L. D. C. I., and Padilla, C. R. (2010b). Bactericidal effect of silver nanoparticles against multidrug-resistant bacteria. World J. Microbiol. Biotechnol. 26, 615-621. doi: 10.1007/s11274-009-0211-3

Lau, K., Zainin, N., Abas, F., and Rukayadi, Y. (2014). Antibacterial and sporicidal activity of Eugenia polyantha Wight against Bacillus cereus and Bacillus subtilis. Int. J. Curr. Microbiol. Appl. Sci. 3, 499-510.

Lee, K.-M., Runyon, M., Herrman, T. J., Phillips, R., and Hsieh, J. (2015). Review of Salmonella detection and identification methods: aspects of rapid emergency response and food safety. Food Control 47, 264-276. doi: 10.1016/j.foodcont. 2014.07.011

Loo, Y. Y., Chieng, B. W., Nishibuchi, M., and Radu, S. (2012). Synthesis of silver nanoparticles by using tea leaf extract from Camellia sinensis. Int. J. Nanomed. 7, 4263-4267. doi: 10.2147/IJN.S33344

Martinez-Castanon, G., Nino-Martinez, N., Martinez-Gutierrez, F., MartinezMendoza, J., and Ruiz, F. (2008). Synthesis and antibacterial activity of silver nanoparticles with different sizes. J. Nanopart. Res. 10, 1343-1348. doi: 10.1007/ s11051-008-9428-6

McNicholl, B. P., McGrath, J. W., and Quinn, J. P. (2007). Development and application of a resazurin-based biomass activity test for activated sludge plant management. Water Res. 41, 127-133. doi: 10.1016/j.watres.2006.10.002

Medda, S., Hajra, A., Dey, U., Bose, P., and Mondal, N. K. (2015). Biosynthesis of silver nanoparticles from Aloe vera leaf extract and antifungal activity against Rhizopus sp. and Aspergillus sp. Appl. Nanosci. 5, 875-880. doi: 10.1007/s13204014-0387-1

Meire, M., Coenye, T., Nelis, H., and De Moor, R. (2012). Evaluation of Nd: YAG and Er: YAG irradiation, antibacterial photodynamic therapy and sodium hypochlorite treatment on Enterococcus faecalis biofilms. Int. Endod. J. 45, 482-491. doi: 10.1111/j.1365-2591.2011.02000.x

Morones, J. R., Elechiguerra, J. L., Camacho, A., Holt, K., Kouri, J. B., Ramírez, J. T., et al. (2005). The bactericidal effect of silver nanoparticles. Nanotechnology 16, 2346-2353. doi: 10.1088/0957-4484/16/10/059

Nadworny, P. L., Wang, J., Tredget, E. E., and Burrell, R. E. (2010). Antiinflammatory activity of nanocrystalline silver-derived solutions in porcine contact dermatitis. Int. J. Inflamm. 7:13. doi: 10.1186/1476-9255-7-13

O'Bryan, C. A., Crandall, P. G., and Ricke, S. C. (2018). Antimicrobial Resistance in Foodborne Pathogens. Food and Feed Safety Systems and Analysis. New York, NY: Elsevier.

Oei, J. D., Zhao, W. W., Chu, L., DeSilva, M. N., Ghimire, A., Rawls, H. R., et al. (2012). Antimicrobial acrylic materials with in situ generated silver nanoparticles. J. Biomed. Mater. Res. B Appl. Biomater. 100, 409-415. doi: 10.1002/jbm.b.31963

Pal, S., Tak, Y. K., and Song, J. M. (2007). Does the antibacterial activity of silver nanoparticles depend on the shape of the nanoparticle? A study of the Gramnegative bacterium Escherichia coli. Appl. Environ. Microbiol. 73, 1712-1720. doi: 10.1128/AEM.02218-06

Paredes, D., Ortiz, C., and Torres, R. (2014). Synthesis, characterization, and evaluation of antibacterial effect of Ag nanoparticles against Escherichia coli O157: H7 and methicillin-resistant Staphylococcus aureus (MRSA). Int. J. Nanomed. 9, 1717-1729. doi: 10.2147/IJN.S57156

Patel, G., Huprikar, S., Factor, S. H., Jenkins, S. G., and Calfee, D. P. (2008). Outcomes of carbapenem-resistant Klebsiella pneumoniae infection and the impact of antimicrobial and adjunctive therapies. Infect. Control Hosp. Epidemiol. 29, 1099-1106. doi: 10.1086/592412

Rai, M., Deshmukh, S., Ingle, A., and Gade, A. (2012). Silver nanoparticles: the powerful nanoweapon against multidrug-resistant bacteria. J. Appl. Microbiol. 112, 841-852. doi: 10.1111/j.1365-2672.2012.05253.x

Selvam, K., Sudhakar, C., Govarthanan, M., Thiyagarajan, P., Sengottaiyan, A., Senthilkumar, B., et al. (2017). Eco-friendly biosynthesis and characterization of silver nanoparticles using Tinospora cordifolia (Thunb.) Miers and evaluate its antibacterial, antioxidant potential. J. Radiat. Res. Appl. Sci. 10, 6-12. doi: 10.1016/j.jrras.2016.02.005

Singh, R., Wagh, P., Wadhwani, S., Gaidhani, S., Kumbhar, A., Bellare, J., et al. (2013). Synthesis, optimization, and characterization of silver nanoparticles from Acinetobacter calcoaceticus and their enhanced antibacterial activity when combined with antibiotics. Int. J. Nanomed. 8, 4277-4290. doi: 10.2147/IJN. S48913

Sondi, I., and Salopek-Sondi, B. (2004). Silver nanoparticles as antimicrobial agent: a case study on E. coli as a model for Gram-negative bacteria. J. Colloid Interface Sci. 275, 177-182. doi: 10.1016/j.jcis.2004.02.012

Subashini, J., Khanna, V. G., and Kannabiran, K. (2014). Anti-ESBL activity of silver nanoparticles biosynthesized using soil Streptomyces species. Bioprocess Biosyst. Eng. 37, 999-1006. doi: 10.1007/s00449-013-1070-8

Tanwar, J., Das, S., Fatima, Z., and Hameed, S. (2014). Multidrug resistance: an emerging crisis. Interdiscip. Perspect. Infect. Dis. 2014: 541340. doi: 10.1155/ 2014/541340

Välimaa, A.-L., Tilsala-Timisjärvi, A., and Virtanen, E. (2015). Rapid detection and identification methods for Listeria monocytogenes in the food chain-a review. Food Control 55, 103-114. doi: 10.1016/j.foodcont.2015.02.037

WHO (2000). Overcoming Antimicrobial Resistance. Geneva: World Health Organization.

WHO (2014). Initiative to Estimate the Global Burden of Foodborne Diseases: Information and Publications. Geneva: World Health Organization.

Woh, P. Y., Thong, K. L., Behnke, J. M., Lewis, J. W., and Zain, S. N. M. (2017). Characterization of nontyphoidal Salmonella isolates from asymptomatic migrant food handlers in Peninsular Malaysia. J. Food Prot. 80, 1378-1383. doi: 10.4315/0362-028X.JFP-16-342

Yuan, Y.-G., Peng, Q.-L., and Gurunathan, S. (2017). Effects of silver nanoparticles on multiple drug-resistant strains of Staphylococcus aureus and Pseudomonas aeruginosa from mastitis-infected goats: an alternative approach for antimicrobial therapy. Int. J. Mol. Sci. 18:E569. doi: 10.3390/ijms1803 0569

Zainin, N., Lau, K., Zakaria, M., Radu, S., Razis, A., Faizal, A., et al. (2013). Antibacterial activity of Boesenbergia rotunda (L.) Mansf. A. extract against Escherichia coli. Int. Food Res. J. 20, 3319-3323.

Zarei, M., Jamnejad, A., and Khajehali, E. (2014). Antibacterial effect of silver nanoparticles against four foodborne pathogens. Jundishapur J. Microbiol. 7, 8720-8723. doi: 10.5812/jjm.8720

Zhang, M., Zhang, K., De Gusseme, B., Verstraete, W., and Field, R. (2014). The antibacterial and anti-biofouling performance of biogenic silver nanoparticles by Lactobacillus fermentum. Biofouling 30, 347-357. doi: 10.1080/08927014. 2013.873419

Zhang, X.-F., Liu, Z.-G., Shen, W., and Gurunathan, S. (2016). Silver nanoparticles: synthesis, characterization, properties, applications, and therapeutic approaches. Int. J. Mol. Sci. 17:E1534. doi: 10.3390/ijms17091534

Conflict of Interest Statement: The authors declare that the research was conducted in the absence of any commercial or financial relationships that could be construed as a potential conflict of interest.

Copyright (c) 2018 Loo, Rukayadi, Nor-Khaizura, Kuan, Chieng, Nishibuchi and Radu. This is an open-access article distributed under the terms of the Creative Commons Attribution License (CC BY). The use, distribution or reproduction in other forums is permitted, provided the original author(s) and the copyright owner(s) are credited and that the original publication in this journal is cited, in accordance with accepted academic practice. No use, distribution or reproduction is permitted which does not comply with these terms. 